\title{
PENGEMBANGAN PBM DENGAN TAHAPAN TPS UNTUK MENINGKATKAN KEMAMPUAN BERPIKIR REFLEKTIF MATEMATIS DAN SELF - EFFICACY SISWA
}

\author{
Indri Cahya Kusuma ${ }^{1}$, Sri Hastuti Noer ${ }^{2}$ Caswita $^{3}$ \\ 1,2,3 Prodi Magister Matematika, FKIP, Universitas Lampung, Jl.Prof. Dr. Sumatri Brojonegoro No.1 Gedong Meneng, \\ Bandar Lampung, Indonesia \\ Hastuti_noer@yahoo.com
}

\begin{abstract}
This study generally uses the R \& D procedure from Borg and Gall (1983: 775) which uses 7 out of 10 stages. In particular, the learning design uses the learning design development model according to Branch (2009: 17) with analysis, design, development, implementation, and evaluation (ADDIE) stages which aim to find out how the results of PBM model development are, and their effectiveness on the ability to think reflective mathematically and student self-efficacy. The subjects of this study were students of class VIII SMPN 20 Bandar Lampung for the 2019/2020 academic year. The research data were obtained through a mathematical reflective thinking test and a self-efficacy scale. The data analysis technique used the t test and $\mathrm{N}$-gain. The results of this study, namely (1) a preliminary study showed the need to develop problem-based learning that focused on the needs and difficulties in high-order thinking of students facilitated by LKPD. (2) learning development has a valid category, learning tools that also have a valid category, namely syllabus, lesson plans, and student worksheet with an average percentage of $80.11 \%$, (3) the practicality and attractiveness of the development has a practical category with an average percentage $84.8 \%$ and interesting category $83.43 \%$, and (4) The results of the effectiveness test showed that the PBM developed with TPS was effective in improving students' mathematical reflective thinking skills with an average $\mathrm{N}$-gain of 0.502. PBM developed with the TPS stage shows that it is more effective than mathematical reflective thinking skills and student self-efficacy with learning that does not use the developed PBM.
\end{abstract}

Keywords: problem-based learning, think pair share, mathematical reflective thinking, self-efficacy.

\begin{abstract}
Abstrak
Penelitian ini secara umum menggunakan prosedur R\&D dari Borg dan Gall (1983:775) yang menggunakan 7 dari 10 tahapan nya. Secara khusus, desain pembelajaran menggunakan model pengembangan desain pembelajaran menurut Branch (2009:17) dengan tahapan analysis, design, development, implementation, dan evaluation (ADDIE) yang bertujuan untuk mengetahui bagaimana hasil pengembangan model PBM, serta efektifitasnya terhadap kemampuan berpikir reflektif matematis dan self efficacy siswa. Subjek penelitian ini adalah siswa kelas VIII SMPN 20 Bandar Lampung Tahun Pelajaran 2019/2020. Data penelitian diperoleh melalui tes berpikir reflektif matematis dan skala self efficacy. Teknik analisis data menggunakan uji t dan $N$ gain.. Hasil penelitian ini, yaitu (1) studi pendahuluan menunjukkan kebutuhan dikembangkannya pembelajaran berbasis masalah yang terfokus pada kebutuhan dan kesulitan dalam berpikir tingkat tinggi siswa yang difasilitasi dengan LKPD. (2) pengembangan pembelajaran memiliki kategori valid, perangkat pembelajaran yang juga memiliki kategori valid yaitu silabus, RPP, dan LKPD dengan rata-rata persentase adalah 80,11\%, (3) Hasil kepraktisan dan kemenarikan pengembangan memiliki kategori praktis dengan rata-rata persentase $84,8 \%$ dan kategori menarik 83,43\%, dan (4) Hasil uji efektivitas menunjukkan bahwa PBM yang dikembangkan dengan TPS efektif dalam meningkatkan kemampuan berpikir reflektif matematis siswa dengan rata-rata $N$-gain sebesar 0,502. PBM yang dikembangkan dengan tahapan TPS menunjukkan lebih efektif dibandingkan kemampuan berpikir reflektif matematis matematis dan self efficacy siswa dengan pembelajaran yang tidak menggunakan PBM yang dikembangkan.
\end{abstract}

Kata kunci: pembelajaran berbasis masalah, think pair share, berpikir reflektif matematis, self efficacy

\section{PENDAHULUAN}

Pendidikan pada dasarnya bertujuan untuk mencerdaskan kehidupan bangsa dari kebodohan dan keterbelakangan. Melalui pendidikan yang bermutu, akan tercipta sumber daya manusia yang berkualitas. Oleh karena itu, pendidikan di Indonesia perlu terus diperbarui agar tercipta dunia 
Pengembangan PBM Dengan Tahapan TPS untuk Meningkatkan Kemampuan Berpikir Reflektif Matematis dan SelfEfficacy Siswa, Indri Cahya Kusuma, Sri Hastuti Noer, Caswita

pendidikan yang bermutu dan bisa mengikuti perkembangan zaman dalam suatu proses yang disebut pembelajaran.

Pembelajaran pada dasarnya merupakan rangkaian kegiatan yang dilaksanakan oleh guru sebagai pendidik dan peserta didik dalam kegiatan pembelajaran untuk mencapai tujuan yang telah ditetapkan dalam kurikulum. Dalam proses pembelajaran di sekolah, matematika merupakan salah satu bidang studi yang menduduki peranan penting dalam pendidikan. Dalam pembelajaran matematika, harapannya siswa dapat mengembangkan diri dalam keterampilan berpikirnya. Salah satu keterampilan berpikir tersebut adalah berpikir tingkat tinggi (High Order Thingking) yang sudah terdapat dalam beberapa poin Standar Kompetensi Lulusan Sekolah Menengah (Permendiknas No. 23 Tahun 2006).

Keterampilan berpikir tingkat tinggi merupakan suatu kemampuan berpikir yang tidak hanya membutuhkan kemampuan mengingat saja, namun membutuhkan kemampuan yang lain yang lebih tinggi, seperti kemampuan berpikir kreatif, kritis, dan reflektif. Krulik (2003) "Higher order thinking skills include critical, logical, reflective thinking, metacognitive, and creative thinking“ bahwa berfikir tingkat tinggi meliputi kritis, logis, berfikir reflektif, matakognisi dan berfikir kreatif.

Berfikir tingkat tinggi salah satunya adalah berfikir reflektif seperti yang telah disebutkan di atas. Berpikir reflektif adalah serangkaian langkah-langkah rasional logis berdasarkan metode ilmiah mendefinisikan, menganalisis, dan memecahkan masalah. (Wikiversity). John Dewey (1933) mendefinisikan berfikir reflektif yaitu "active, persistent, and careful consideration of anybelief or supposedfrom of knowledge inthe lightofthe grounds that supportitand the conclusionto whichittends" . Bahwa berfikir reflektif adalah sesuatu yang dilakukan dengan aktif, gigih, dan penuh pertimbangan keyakinan didukung oleh alasan yang jelas dan dapat membuat kesimpulan/memutuskan sebuah solusi untuk masalah yang diberikan.

Menurut Santrock (2010) dalam Suharna (2013:147), siswa yang memiliki gaya reflektif cenderung menggunakan lebih banyak waktu untuk merespons dan merenungkan akurasi jawaban. Individu reflektif sangat lamban dan berhati-hati dalam memberikan respons, tetapi cenderung memberikan jawaban secara benar.. Siswa yang reflektif lebih mungkin melakukan tugas-tugas seperti mengingat informasi yang terstruktur, membaca dengan memahami dan menginterpretasikan teks, memecahkan masalah dan membuat keputusan.

Selain kemampuan berpikir reflektif, terdapat faktor internal yang ada pada diri siswa dan memberikan pengaruh terhadap keberhasilan siswa dalam menyelesaikan tugas atau masalah tertentu. Faktor internal yang dimaksud adalah self-efficacy siswa. Menurut Bandura (2002), self-efficacy adalah suatu belief (keyakinan) mengenai kemampuan individu untuk melakukan sesuatu hal ketika berada dalam berbagai macam kondisi dengan apapun keterampilan yang dimilikinya saat ini. Dalam hal ini, artinya self-efficacy memengaruhi diri siswa dalam berpikir, merasa, memotivasi diri, dan bertindak. 
Berdasarkan hal tersebut, guru perlu membuat desain pembelajaran yang mampu membangkitkan potensi siswa dalam menggunakan kemampuan berpikirnya untuk menyelesaikan masalah. Pembelajaran yang bermakna akan memberikan dampak yang baik terhadap kemampuan siswa. Guru dalam pembelajaran matematika bertugas untuk membantu siswa dalam membangun konsep-konsep matematika dengan kemampuannya sendiri melalui proses internalisasi sehingga membentuk suatu konsep baru yang bermakna. Pembelajaran bermakna bisa didapatkan dari pembelajaran yang melibatkan lingkungan belajar.

Pembelajaran lingkungan dekat dengan pembelajaran berbasis masalah(PBM). PBM adalah suatu model pembelajaran yang menghadapkan siswa dalam mengerjakan masalah matematis dengan kemampuan yang dimilikinya dan siswa dituntut untuk menyelesaikan pemecahan masalah tersebut. Hasil penelitian Tatang Herman (2007) menjelaskan bahwa PBM dapat meningkatkan kemampuan berpikir matematis tingkat tinggi siswa SMP, baik ditinjau dari perbedaan kualifikasi sekolah, tingkat kemampuan matematika siswa, ataupun perbedaan gender. Dengan demikian, PBM sangat potensial diterapakan di lapangan dalam upaya meningkatkan kualitas pendidikan. Dampak positif dari strategi mengajar PBM secara signifikan membantu dalam mengembangkan berpikir reflektif siswa.

Namun, PBM sendiri mempunyai kelemahan dalam mengaplikasikannya di kelas. Menurut Sanjaya (2006) terdapat beberapa kekurangan PBM, antara lain Ketika siswa tidak berminat pada masalahnya, mereka enggan untuk mencoba. Artinya, tidak menutup kemungkinan PBM hanya cocok diterapkan bagi siswa yang memiliki kemampuan awal tinggi saja. Hal tersebut menyebabkan sebagian siswa lain yang berkemampuan awal rendah menjadi semakin pasif. Bahkan, ketika dalam sebuah kelompok belajar sebagian siswa hanya berdiam diri atau sekedar mengobrol sehingga hanya menyumbang nama dan mengandalkan temannya untuk menyelesaikan pekerjaan. Salah satu hal yang dapat dilakukan untuk menutupi kelemahan tersebut adalah dengan mengkolaborasikan PBM dengan model pembelajaran kooperatif (Cooperative learning).

Cooperative learning dapat menguntungkan bagi siswa yang berprestasi rendah maupun tinggi yang mengarjakan tugas akademik bersama-sama. Proses belajar melaui cooperative learning diharapkan siswa lebih aktif menyalurkan pengetahuan, gagasan, dan menerima gagasan dari temannya. Siswa dalam kelompok akan belajar mendengarkan ide atau gagasan orng lain, berdiskusi setuju atau tidak setuju, menawarkan atau menerima kritikan yang membangun dan siswa merasa tidak terbebani ketika ternyata pekerjaan dalam menyelesaikan masalah bernilai salah. Salah satu tipe pembelajaran cooperative learning adalah Think Pair Share(TPS).

Huda (2015:206) mengatakan Think Pair Share (TPS) merupakan strategi pembelajaran yang dikembangkan pertama kali oleh Profesor Frank Lyman di Universitas of Maryland pada 1981 dan diadopsi oleh banyak penulis dibidang pembelajaran kooperatif pada tahun-tahun selanjutnya. Strategi ini memperkenalkan gagasan tentang waktu 'tunggu atau berpikir' (wait of think time) pada elemen interaksi pembelajaran kooperatif yang saat ini menjadi salah satu faktor ampuh dalam meningkatkan 
Pengembangan PBM Dengan Tahapan TPS untuk Meningkatkan Kemampuan Berpikir Reflektif Matematis dan SelfEfficacy Siswa, Indri Cahya Kusuma, Sri Hastuti Noer, Caswita

respons siswa terhadap pertanyaan. Jadi, dalam metode Think Pair Share (TPS) ini, siswa diberi waktu oleh guru untuk berpikir dan menjawab terhadap pertanyaan yang telah diberikan kepadanya.

Strategi ini memiliki prosedur yang secara ekslipit memberikan siswa lebih banyak waktu untuk berpikir, menjawab, dan saling membantu satu sama lain (Suprihatiningrum,2013). Oleh karena itu, di dalam strategi ini siswa diharapkan berperan sangat aktif dalam sebuah pembelajaran baik dalam hal berpikir, menjawab, maupun berdiskusi saling membantu antara siswa yang satu dengan yang lainnya. Kemudian dalam keaktifan siswa tersebut diharapkan potensi-potensi yang dimiliki oleh siswa dapat berkembang secara optimal. Pada dasarnya TPS mengacu pada kegiatan saling membantu sesama anggota kelompok dalam menyelesaikan masalah. Hal ini bisa mengurangi rasa cemas siswa dalam berinteraksi bertukar pikiran dibandingkan dengan berinteraksi dengan guru. Dengan demikian rasa percaya diri siswa akan meningkat dan mempengaruhi proses dan hasil belajar siswa.

Beberapa Penelitian dengan Think Pair Share juga telah dilakukan oleh beberapa peneliti, diantaranya berdasarkan penelitian Hidayatun (2015) pembelajaran matematika dengan model pembelajaran kooperatif tipe Think Pair Share (TPS) efektif ditinjau dari pemahaman konsep matematika siswa. Selain itu, hasil penelitian Arki,dkk (2017) juga mengatakan bahwa metode pembelajaran kooperatif tipe Think Pair Share (TPS) dapat meningkatkan hasil belajar siswa.

Berdasarkan hasil studi pendahuluan penulis di SMPN 20 Bandarlampung, di sekolah tersebut sudah menggunakan kurikulum 2013 revisi 2017, baik buku penunjang, perangkat kelas, sampai sistem penilaian. Kurikulum 2013 revisi 2017 menuntut model pembelajaran yang mengacu pada pendekatan pembelajaran saintifik, termasuk di dalamnya tujuan pengajaran, tahap-tahap dalam kegiatan pembelajaran, lingkungan pembelajaran, dan pengelolaan kelas. Salah satu model pembelajaran yang direkomendasikan oleh kurikulum ini adalah PBM. PBM juga adalah model pembelajaran yang sering digunakan oleh guru matematika SMPN 20 bandarlampung meskipun dalam pelaksanaannya belum sempurna.

Berdasarkan hasil wawancara dengan guru matematika di SMPN 20, ketidaksempurnaan tersebut adalah karena pada pelaksanaan model PBM di kelas, guru masih juga menggunakan metode ceramah untuk menjelaskan materi. Setelah itu siswa mengerjakan soal latihan yang ada di buku paket. Menurut mereka, hal tersebut dianggap lebih efektif dan memudahkan guru dalam pelaksanaan proses pembelajaran. Mereka juga mengatakan, jalan tersebut mereka gunakan karena terkadang kondisi siswa tidak siap menggunakan model pembelajaran yang direncanakan. Padahal, hal tersebut akan mengakibatkan ketergantungan peserta didik akan penjelasan dari guru semakin nampak dalam hal memahami materi. Sehingga siswa semakin sulit untuk memiliki self eficacy dan kemampuan berpikir tingkat tinggi karena hanya biasa menyelesaikan soal sesuai contoh yang diberikan oleh guru.

Berdasarkan uraian tersebut, penulis tertarik untuk mengembangkan suatu model pembelajaran yang mampu mengatasi permasalahan dalam pembelajaran matematika di SMPN 20 Bandarlampung dengan judul : Pengembangan PBM dengan tahapan TPS untuk meningkatkan kemampuan berpikir reflektif matematis dan self eficacy siswa. 
Tujuan dari penelitian ini adalah untuk mengetahui produk pengembangan, mengetahui proses pengembangan, dan untuk mengetahui efektivitas pengembangan pembelajaran berbasis masalah dengan tahapan think pair share untuk meningkatkan kemampuan berpikir reflektif dan self eficacy siswa

\section{METODE}

Jenis penelitian ini adalah penelitian pengembangan atau Research and Development $(R \& D)$. Menurut Borg dan Gall (2003), penelitian pengembangan adalah penelitian yang berorientasi untuk mengembangkan dan memvalidasi produk-produk yang digunakan dalam pendidikan. Dalam penelitian ini, pengembangan yang dilakukan adalah pengembangan pembelajaran berbasis masalah dengan tahapan think pair share untuk meningkatkan kemampuan berpikir reflektif dan self-efficacy siswa.

\section{Subjek Penelitian}

Subjek dalam penelitian ini dibagi dalam beberapa tahap berikut.

\section{Subjek Validasi Pengembangan Pembelajaran}

Subjek validasi pengembangan pembelajaran dalam penelitian ini adalah dua orang ahli yang terdiri atas dua orang sebagai ahli materi, ahli desain pembelajaran, dan ahli media sekaligus, serta satu ahli dibidang psikologi. Berikut dijabarkan secara lebih rinci tentang subjek validasi penembangan pembelajaran dalam 1

\section{Tabel 1.}

Subjek Validasi Pengembangan Pebelajaran Berbasis Masalah Untuk Meningkatkan Kemampuan Berpikir Reflektif dan Self- Efficacy siswa.

\begin{tabular}{|l|l|l|}
\hline \multicolumn{1}{|c|}{$\begin{array}{c}\text { Subjek Validasi } \\
\text { (Validator) }\end{array}$} & \multicolumn{1}{|c|}{ Nama Validator } & \multicolumn{1}{|c|}{ Instrumen Validasi } \\
\hline Ahli desain pembelajaran & $\begin{array}{l}\text { 1. Mella Triana, M.Pd. } \\
\text { 2. Avissa Purnama Yanti, M.Pd. }\end{array}$ & $\begin{array}{l}\text { Desain Pengembangan } \\
\text { Pembelajaran, RPP, Silabus, } \\
\text { LKPD }\end{array}$ \\
\hline $\begin{array}{l}\text { Ahli materi bidang } \\
\text { matematika }\end{array}$ & $\begin{array}{l}\text { 1. Mella Triana, M.Pd. } \\
\text { 2. Avissa Purnama Yanti, M.Pd. }\end{array}$ & $\begin{array}{l}\text { Soal Evaluasi Kemampuan } \\
\text { Berpikir Reflektif }\end{array}$ \\
\hline Ahli media dan materi & $\begin{array}{l}\text { 1. Mella Triana, M.Pd. } \\
\text { 2. Avissa Purnama Yanti, M.Pd. }\end{array}$ & LKPD \\
\hline Ahli Psikologi & Veni Permatasari, M.Pd. & Skala Self-Efficacy \\
\hline
\end{tabular}

\section{Subjek Uji Coba Lapangan awal}

Subjek uji coba lapangan awal pada tahap ini ada 2 yaitu (a) subjek uji coba lapangan awal untuk pengembangan pembelajaran berbasis masalah ini yaitu peserta didik kelas VIII B, dan (b) subjek uji coba lapangan awal untuk soal kemampuan berpikir reflektif matematis yaitu 30 peserta didik kelas IX A yang sudah menempuh materi Sistem Persamaan Linier DuaVariabel (SPLDV). 
Pengembangan PBM Dengan Tahapan TPS untuk Meningkatkan Kemampuan Berpikir Reflektif Matematis dan SelfEfficacy Siswa, Indri Cahya Kusuma, Sri Hastuti Noer, Caswita

\section{Uji Lapangan}

Subjek uji lapangan adalah seluruh peserta didik kelas VIII A dan VIII H yang terdiri dari kelas eksperimen dan kelas kontrol. Kelas eksperimen yaitu kelas VIII A yang berjumlah 30 siswa dan kelas kontrol yaitu kelas VIII H dengan jumlah 30 siswa juga.

\section{Prosedur Penelitian}

Prosedur penelitian yang dilakukan peneliti dalam penelitian pengembangan ini diadaptasi dari langkah-langkah pengembangan yang dikembangkan oleh Borg dan Gall tersebut dengan pembatasan. Borg \& Gall (dalam Emzir, 2013: 271) menyatakan bahwa dimungkinkan untuk membatasi penelitian dalam skala kecil, termasuk membatasi langkah penelitian. Penerapan langkahlangkah pengembangannya disesuaikan dengan kebutuhan peneliti. Mengingat keterbatasan waktu dan dana yang dimiliki oleh peneliti, maka langkah-langkah tersebut disederhanakan menjadi tujuh langkah dari sepuluh langkah pengembangan yang digambarkan sebagai berikut.

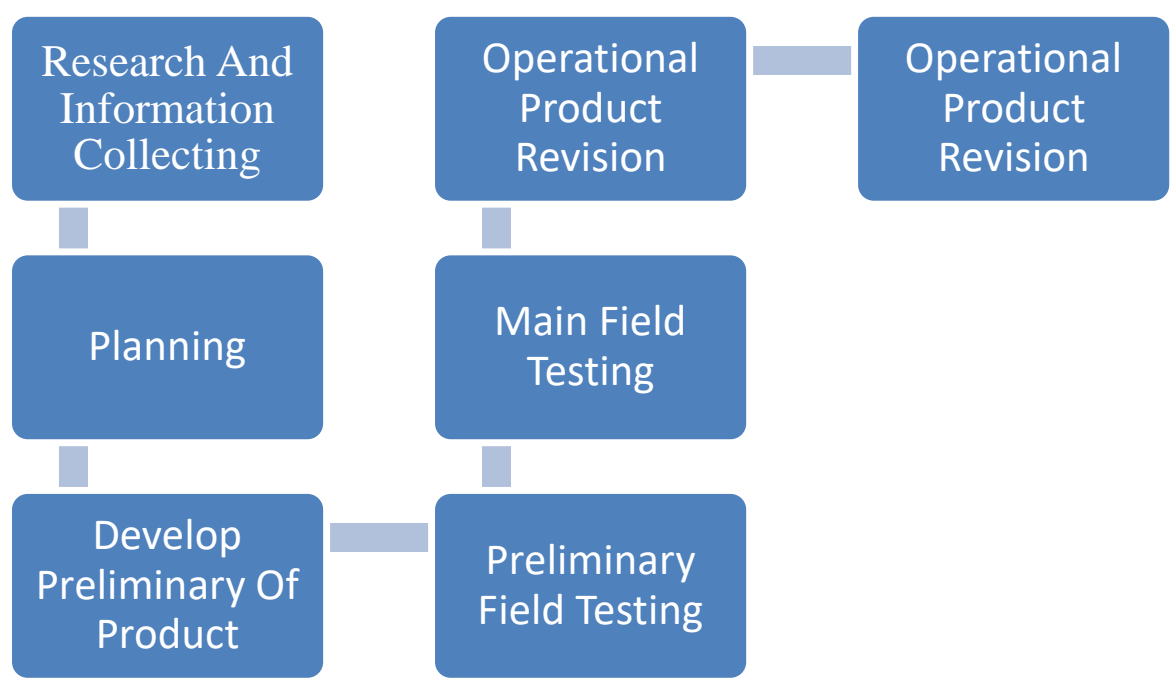

Gambar 1. Prosedur Penelitian

\section{Instrumen Penelitian}

Instrumen yang digunakan pada penelitian ini terdiri dari dua jenis instrumen, yaitu nontes dan tes. Instrumen - instrumen tersebut akan dijelaskan sebagai berikut.

\section{Instrumen Nontes}

Terdapat dua jenis instrumen nontes yang digunakan dalam penelitian ini yaitu wawancara dan angket. Wawancara digunakan saat studi pendahuluan dengan mewawancarai guru matematika, siswa kelas VIII, dan siswa kelas IX mengenai kondisi awal siswa dan model yang digunakan dalam pembelajaran. Selanjutnya, instrument kedua yang diguanakan dalam penelitian ini adalah angket. Angket tersebut berupa angket skala self-efficacy dan angket hasil pengembangan pembelajaran dan perangkat pembelajaran diesuaikan dengan tahapan penelitian. Instrumen ini digunakan untuk mendapatkan data mengenai pendapat para ahli (Validator) terhadap hasil pengembangan pembelajaran dan perangkat pembelajaran yang akan disusun. Instrumen ini akan menjadi pedoman 
dalam merevisi dan menyempurnakan desain pengembangan pembelajaran dan perangkat pembelajaran yang mendukung

\section{Instrumen Tes}

Instrumen tes yang digunakan adalah tes kemampuan berpikir reflektif matematis. Instrumen dalam tes ini berupa soal uraian yang diberikan secara individual dan bertujuan untuk mengukur kemampuan berpikir reflektif matematis siswa. Penilaian hasil tes dilakukan sesuai dengan indikatorindikator kemampuan berpikir reflekktif matematis, yaitu reacting (bereaksi dengan perhatian pribadi terhadap peristiwa/situasi/masalah), comparing (membandingkan reaksi dengan pengalaman yang lain, seperti mengacu pada suatu prinsip umum, suatu teori), contemplating (mengutamakan pembangunan pemahaman diri yang mendalam terhadap permasalahan, seperti mengutamakan isu-isu pembelajaran, metode- metode latihan, tujuan selanjutnya, sikap, etika, memfokuskan diri dalam proses menguraikan, menginformasikan, mempertentangkan, dan merekonstruksi situasisituasi).

\section{HASIL}

\section{Proses dan Hasil Pengembangan PBM dengan tahapan TPS.}

\section{Studi Pendahuluan dan Pengumpulan Data (Research and information collecting )}

Berdasarkan observasi dari hasil penelitian pendahuluan diperoleh bahwa siswa masih bergantung pada penjelasan guru dalam memahami materi dan respon yang ditunjukkan adalah siswa kurang aktif dalam pembelajaran di kelas, sehingga membuat guru harus secara berkala meminta pesert didik mengerjakan tugas atau soal sebagai bahan evaluasi materi. Guru matematika kelas VIII SMPN 20 Bandarlampung mengatakan bahwa banyak siswa yang mendapatkan nilai di bawah KKM. Penyebab hal tersebut diduga karena pemahaman konsep siswa terhadap materi di jenjang sebelumnya masih kurang maksimal, sehingga cukup sulit untuk siswa memahami materi di bab ataupun di jenjang berikutnya. Kemudian disebutkan juga, mungkin metode pembelajaran yang digunakan untuk siswa dan materi saat pembelajaran yang kurang tepat.

Salah satu guru matematika kelas VIII di SMPN 20 Bandarlampung juga mengemukakakan bahwa pada saat pembelajaran, siswa masih mengalami kesulitan dalam menyelesaikan soal-soal matematika yang menuntut kemampuan berpikir tingkat tinggi dan siswa meragukan kemampuannya dalam menyelesaikan soal tersebut, dikarenakan siswa tidak memahami konsep materi yang dipelajari dengan baik. Hal ini mengartikan bahwa siswa belum mampu menghubungkan pengetahuan yang diperolehnya untuk menyelesaikan permasalahan baru yang berkaitan dengan pengetahuan lamanya. Masalah tersebut berkaitan dengan kemampuan berpikir reflektif matematis dan self-efficacy siswa. Beberapa saran yang diberikan oleh guru saat wawancara adalah menggunakan model pembelajaran yang tepat untuk siswa dan disusunnya LKPD khusus yang dapat menunjang dan meningkatkan kemampuan berpikir reflektif matematis dan self-efficacy siswa dalam pembelajaran matematika. 
Pengembangan PBM Dengan Tahapan TPS untuk Meningkatkan Kemampuan Berpikir Reflektif Matematis dan SelfEfficacy Siswa, Indri Cahya Kusuma, Sri Hastuti Noer, Caswita

\section{Perencanaan (Planning)}

Hal-hal yang dilakukan pada tahap ini yaitu (1) merumuskan tujuan penelitian yang terfokus pada pengembangan PBM dengan menggunakan tahapan TPS untuk meningkatkan kemampuan berpikri reflektif matematis dan self-efficacy siswa. (2) menentukan subjek dan waktu penelitian yaitu siswa kelas VIII A sebagai kelas eksperimen dan VIII H kelas control. Waktu penelitian adalah semester ganjil tahun ajaran 2019/2020. (3) memilih materi sesuai hasil studi pendahuluan yaitu sistem persamaan linier dua variable (SPLDV). (4) menentukan banyak pertemuan yaitu 4 kali pertemuan berdasarkan materi. Pertemuan dilaksanakan 2 kali dalam seminggu, yaitu Hari Selasa dan Kamis untuk VIIIA sebagai kelas eksperimen dan Hari Selasa dan Jumat untuk kelas VIIIH sebagai kelas kontrol.

\section{Pengembangan Desain Produk Awal (Develop Preliminary form of product)}

Pengembangan desain produk yang dilakukan yaitu pengembangan pembelajaran berbasis masalah dengan menggunakan tahapan Think Pair Share yang memanfaatkan perangkat pembelajaran berupa silabus, RPP, LKPD, soal evaluasi kemampuan berpikir reflektif matematis, dan skala untuk mengukur self-efficacy siswa. Pengembangan desain pembelajaran dan perangkat pembelajaran yang telah disusun kemudian divalidasi dan direvisi berdasarkan saran para ahli dibidangnya.

\section{Uji Coba Lapangan Awal (Preliminary Field Testing)}

Berdasarkan saran perbaikan dari ahli desain pembelajaran, ahli materi, dan ahli media selanjutnya diujicobakan kepada siswa. Uji coba lapangan awal pada penelitian ini yaitu memberikan pembelajaran menggunakan pengembangan pembelajaran berbasis masalah dengan Tahapan Think Pair Share kepada siswa di luar kelas eksperimen dan control yang berjumlah 30 siswa. Uji coba ini bertujuan mengetahui tanggapan siswa terkait kemampuan memahami dan melaksanakan pembelajaran meliputi bagaimana pemberian motivasi, kejelasan materi, keterlaksanaan kegiatan pembelajaran, pengelolaan kelas, keefektifan waktu, dan penggunaan bahasayg baik dan mudah serta mudah dipahami. Instrumen yang digunakan berupa angket skala repon. Hasil tanggapan siswa memperoleh nilai 213 dari skor ideal 270 atau sekitar 78,89\% dan masuk dalam kategori praktis/baik.

Sebelum pelaksanaan Pretest dan Postest pada kelas kontrol dan ekperimen, soal evaluasi kemampuan penalaran matematis diujicobakan terlebih dahulu kepada siswa yang telah mempelajari SPLDV yaitu siswa kelas IX A pada tanggal 26 November 2019. Tujuan dilakukannya uji coba terhadap soal evaluasi kemampuan berpikir reflektif matematis adalah agar bisa digunakan oleh siswa baik dari kemampua tinggi, sedang, maupun rendah. Kemudian soal evaluasi kemampuan penalaran matematis direduksi sesuai tingkat kevalidan, reliable, tingkat kesukaran dan daya pembeda menghasilkan 4 soal yang memiliki tingkat kevalidan, reliable, tingkat kesukaran dan daya pembeda yang sesuai dan dapat digunakan di lapangan.

\section{Merevisi Hasil Uji Coba (Main Product Revision)}

Berdasarkan angket hasil tanggapan peaserta didik terhadap pembelajaran berbasis masalah pada kelas uji coba lapangan awal, ada beberapa pendapat dan saran dari siswa yang dapat dijadikan 
saran perbaikan terhadap pembelajran yang telah berlangsung yaitu beberapa siswa mengemukakan bahwa suasana belajar masih perlu disegarkan lagi agar terasa lebih menyenangkan dan memulihkan konsentrasi belajar saat ditengah pelajaran. Sebaiknya guru mempunyai cara untuk mengatasi masalah tersebut. Berdasarkan saran di atas maka pembelajaran sebaiknya dilakukan berdasarkan masukanmasukan yang telah dijabarkan yaitu sebaiknya guru dapat membuat pembelajaran tidak tegang.

\section{Uji Coba Lapangan ( Main Field Testing)}

Uji lapangan adalah tahap menguji kefektivitasan pembelajaran berbasis masalah dengan tahapan think pair share untuk meningkatkan kemampuan berpikir reflektif matematis dan selfefficacy siswa. Uji coba lapangan ini dilakukan pada kelas VIII A SMPN 20 Bandarlampung sebagai kelas eksperimen dan kelas VIII H sebagai kelas control dengan jumlah siswa masing-masing kelas 30 siswa.

Pembelajaran berbasis masalah dengan tahapan think pair share dilaksanakan di kelas eksperimen yaitu VIIIA, dimana saat pembelajaran diberikan LKPD untuk masing-masing siswa yang telah direvisi dan guru berperan sebagai fasilitator yang mengarahkan jalannya pembelajaran agar berjalan efektif. Perangkat pembelajaran yang digunakan meliputi silabus, RPP, LKPD, soal evaluasi kemampuan berpikir reflektif matematis, dan angket self-efficacy sesuai dengan pengembangan pebelajaran pada penelitian ini untuk meningkatkan kemampuan berpikir reflektif matematis dan selfefficacy siswa.

Jumlah pertemuan pada kelas eksperimen adalah 4 pertemuan. Pada setiap pertemuan terdiri dari 3 kegiatan pokok yaitu kegiatan pendahuluan, kegiatan inti, dan kegiatan penutup. Pada awal pembelajaran kelas eksperimen maupun kelas kontrol diberikan pretest untuk mengetahui kemampuan awal berpikir reflektif matematis siswa dan skala self-efficacy untuk mengetahui selfefficacy awal siswa. Kemudian di akhir pembelajaran diberikan posttest dan skala self-efficacyuntuk menguji peningkatan kemampuan berpikir reflektif matematis dan self-efficacysiswa.

\section{Penyempurnaan produk hasil uji coba lapangan (Operasional product revision)}

Revisi produk hasil uji coba lapangan berasal dari angket tanggapan guru terhadap pengembangan pembelajaran, angket tanggapan peserta didik yang menjadi subjek uji lapangan. Angket-angket tersebut dianalisis untuk mengetahui kepraktisan dan kemenarikan pengembangan pembelajaran berbasis masalah yang dikembangkan dengan tahapan Think pair share.Adapun perbaikan yang dilakukan yaitu memperbaiki bebrapa kesalahan penulisna pada silabus,RPP, dan LKPD, memperbaiki kunci jawaban karena ada kekeliruan, serta pada inti kegiatan pembelajaran, pemberian ice breaking di tengah pembelajaran mampu menyegarkan siswa kembali dan memulihkan konsentrasi untuk siap belajar lagi.

\section{Hasil Validitas, kepraktisan, dan kemenarikan Pengembangan PBM dengan TPS}

Berdasarkan penilaian para ahli untuk pengembangan pembelajaran, silabus, RPP, dan LKPD memperoleh valid dengan rata-rata persentase $80,11 \%$. Maka pengembangan PBM dengan tahapan TPS masuk dalam kategori valid dan dapat digunakan di lapangan. 
Pengembangan PBM Dengan Tahapan TPS untuk Meningkatkan Kemampuan Berpikir Reflektif Matematis dan SelfEfficacy Siswa, Indri Cahya Kusuma, Sri Hastuti Noer, Caswita

Produk pengembangan dikatakan praktis jika produk tersebut bias diterapkan oleh guru dan mudah diterapkan oleh siswa. Penilaian kepraktisan pengembangan pembelajaran, dan perangkatnya dilakukan melalui (1) angket tanggapan guru matematika, (2) angket tanggapan siswa uji coba awal, dan (3) angket tanggapan siswa uji coba. Penjelasannya dijabarkan sebagai berikut.

Tabel 1.

Kategori Penilaian Tanggapan Guru Matematika

\begin{tabular}{|c|l|c|c|c|c|}
\hline No & \multicolumn{1}{|c|}{ Komponen } & $\begin{array}{c}\text { Jumlah } \\
\text { Skor }\end{array}$ & $\begin{array}{c}\text { Jumlah } \\
\text { Skor Ideal }\end{array}$ & $\begin{array}{c}\text { Persentase } \\
\text { Nilai }\end{array}$ & $\begin{array}{c}\text { Kategori } \\
\text { Penilaian }\end{array}$ \\
\hline 1 & Langkah Pembelajaran & 27 & 36 & $75 \%$ & Valid \\
\hline 2 & Silabus & 8 & 8 & $100 \%$ & Valid \\
\hline 3 & RPP & 11 & 12 & 91,667 & Valid \\
\hline 4 & LKPD & 7 & 8 & $87,5 \%$ & Valid \\
\hline 5 & Alokasi Waktu & 13 & 16 & $81,25 \%$ & Valid \\
\hline \multicolumn{2}{|l|}{ Jumlah } & 66 & 80 & $82,5 \%$ & Valid \\
\hline
\end{tabular}

Tabel 2.

Kategori penilaian Tanggapan siswa uji coba lapangan awal

\begin{tabular}{|l|l|l|l|l|}
\hline \multicolumn{1}{|c|}{ Kriteria } & Jumlah Skor & Jumlah Skor Ideal & $\begin{array}{c}\text { Persentase } \\
\text { Nilai }\end{array}$ & $\begin{array}{c}\text { Kategori } \\
\text { Penilaian }\end{array}$ \\
\hline $\begin{array}{l}\text { Langkah- } \\
\text { Langkah PBM } \\
\text { dengan Tahapan } \\
\text { TPS }\end{array}$ & 141 & 180 & 78,33 & Praktis \\
\hline $\begin{array}{l}\text { Penggunaan } \\
\text { LKPD }\end{array}$ & 72 & 90 & $80 \%$ & Praktis \\
\hline Jumlah & 213 & 270 & 78,889 & Praktis \\
\hline
\end{tabular}

Tabel 3.

Kategori penilaian Tanggapan siswa uji coba lapangan

\begin{tabular}{|l|c|c|c|c|}
\hline \multicolumn{1}{|c|}{ Kriteria } & Jumlah Skor & Jumlah Skor Ideal & $\begin{array}{c}\text { Persentase } \\
\text { Nilai }\end{array}$ & $\begin{array}{c}\text { Kategori } \\
\text { Penilaian }\end{array}$ \\
\hline $\begin{array}{l}\text { Langkah- } \\
\text { Langkah PBM } \\
\text { dengan Tahapan } \\
\text { TPS }\end{array}$ & 152 & 180 & $84,44 \%$ & Praktis \\
\hline $\begin{array}{l}\text { Penggunaan } \\
\text { LKPD }\end{array}$ & 77 & 90 & 85,56 & $\begin{array}{l}\text { Sangat } \\
\text { Praktis }\end{array}$ \\
\hline Jumlah & 229 & 270 & $84,8 \%$ & Praktis \\
\hline
\end{tabular}

\section{Hasil Efetktivitas pembelajaran Berbasis Masalah dengan Tahapan Think Pair Share}

Data untuk mengetahui efektifitas pembelajaran berbasis masalah dengan tahapan think pair share dalam penelitian ini dilihat dari nilai pretes dan nilai posttest. Data dianaisis dengan uji statistic yaitu uji kesamaan dua rata-rata (uji-t) dan dilanjutkan uji sampel ana yang rata-ratanya lebih tinggi atau besarnya peningkatan (indeks gain). Pengujian hipotesis dilakukan dengan bantuan SPSS for windows versi 20 , diterangkan secara rinci sebagai berikut. 


\section{Uji t skor pretest}

Kemampuan awal berpikir reflektif matematis dan self-efficacy siswa yang menggunakan PBM yang dikembangkan dengan siswa yang tidak menggunakan pembelajaran PBM yang dikembangkan diperoleh dari skor hasil pretest dan skala self-efficacy yang diberikan pada awal pertemuan. Data hasil pretest dan skala self-efficacy tersebut kemudian dianalisis untuk mengetahui apakah siswa pada kedua kelas tersebut memiliki kemampuan awal berpikir reflektif matematis dan self-efficacy yang sama.Dari pengumpulan data yang telah dilakukan, diperoleh data kemampuan awal berpikir reflektif matematis dan self-efficacy siswa pada kedua kelas seperti yang disajikan pada Tabel 3 dan 4

\section{Tabel 4.}

Data Skor Awal Kemampuan Berpikir Reflektif Siswa

\begin{tabular}{|c|c|c|c|c|c|}
\hline $\begin{array}{c}\text { Kelompok } \\
\text { Penelitian }\end{array}$ & $\begin{array}{c}\text { Banyak } \\
\text { Siswa }\end{array}$ & Rata-rata & $\begin{array}{c}\text { Simpangan } \\
\text { Baku }\end{array}$ & $\begin{array}{c}\text { Nilai } \\
\text { Terendah }\end{array}$ & $\begin{array}{c}\text { Nilai } \\
\text { Tertinggi }\end{array}$ \\
\hline Eksperimen & 30 & 52,67 & 11,29 & 31 & 66 \\
\hline Kontrol & 30 & 57,86 & 12,8 & 31 & 78 \\
\hline
\end{tabular}

Nilai Maksimum Ideal (NMI) $=100$

Tabel 5.

Data Skor Awal Self-Efficacy Siswa

\begin{tabular}{|c|c|c|c|c|c|}
\hline $\begin{array}{c}\text { Kelompok } \\
\text { Penelitian }\end{array}$ & $\begin{array}{c}\text { Banyak } \\
\text { Siswa }\end{array}$ & Rata-rata & $\begin{array}{c}\text { Simpangan } \\
\text { Baku }\end{array}$ & $\begin{array}{c}\text { Skor } \\
\text { Terendah }\end{array}$ & $\begin{array}{c}\text { Skor } \\
\text { Tertinggi }\end{array}$ \\
\hline Eksperimen & 30 & 54,9 & 10,8 & 43,8 & 71,9 \\
\hline Kontrol & 30 & 55,1 & 7,54 & 43,7 & 68,7 \\
\hline
\end{tabular}

Skor Maksimum Ideal (SMI) $=96$

Berdasarkan Tabel 3 memperlihatkan bahwa rata-rata kemampuan berpikir reflektif matematis siswa kelas eksperimen lebih rendah daripada rata-rata kemampuan berpikir reflektif matematis siswa kelas kontrol. Selanjutnya Tabel 4 memperlihatkan bahwa rata-rata self-efficacy awal siswa kelas eksperimen lebih tinggi daripada rata-rata self-efficacy awal siswa kelas kontrol. Selanjutnya, untuk menguji apakah ada perbedaan kemampuan berpikir reflektif matematis dan selfefficacykedua kelas sampel yang juga berlaku pada populasi maka dilakukan analisis data.

Dari hasil uji normalitas dan uji homogenitas sebagai uji prasyarat sebelum melakukan uji t, diketahui bahwa data skor awal kemampuan berpikir reflektif matematis dan self-efficacy siswa pada kedua sampel dalam penelitian ini berasal dari populasi yang berdistribusi normal dan kedua kelompok populasi memiliki varian yang homogen atau sama. Oleh karena itu, uji hipotesis menggunakan uji kesamaan dua rata-rata, yaitu uji $t$. Dengan menggunakan program SPPS versi 20.0, diperoleh hasil seperti pada Tabel 5 dan 6 . 
Pengembangan PBM Dengan Tahapan TPS untuk Meningkatkan Kemampuan Berpikir Reflektif Matematis dan SelfEfficacy Siswa, Indri Cahya Kusuma, Sri Hastuti Noer, Caswita

Tabel 6.

Hasil Uji t Skor Awal Kemampuan Berpikir Reflektif Matematis

\begin{tabular}{|c|c|c|c|c|}
\hline Pembelajaran & $\begin{array}{l}\text { Rata- } \\
\text { Rata }\end{array}$ & $\mathbf{t}_{\text {hitung }}$ & $D f$ & Sig. (2-tailed) \\
\hline PBM hasil Pengembangan & 52,67 & & & \\
\hline $\begin{array}{l}\text { PBM sebelum } \\
\text { pengembangan }\end{array}$ & 57,8 & 2,149 & 58 & 0,056 \\
\hline
\end{tabular}

Tabel 7.

Hasil Uji t Skor Awal Self-Efficacy Siswa

\begin{tabular}{|l|c|c|c|c|}
\hline \multicolumn{1}{|c|}{ Pembelajaran } & $\begin{array}{c}\text { Rata- } \\
\text { Rata }\end{array}$ & $\mathbf{t}_{\text {hitung }}$ & Df & Sig. (2-tailed) \\
\cline { 1 - 2 } PBM hasil Pengembangan & 54,9 & -161 & 58 & 0,873 \\
\cline { 1 - 3 } $\begin{array}{c}\text { PBM sebelum } \\
\text { pengembangan }\end{array}$ & 55,17 & & & \\
\hline
\end{tabular}

Berdasarkan Tabel 5 dan 6, terlihat bahwa nilai probabilitas (Sig.) kurang dari 0,05. Ini berarti bahwa hipotesis nol diterima.Oleh karena itu dapat disimpulkan bahwa tidak ada perbedaan yang signifikan antara kemampuan awal berpikir reflektif matematis dan self-efficacy siswa yang menggunakan pembelajaran PBM yang dikembangkan dan siswa yang tidak menggunakan pembelajaran PBM yang dikembangkan.

Uji-t Skor Postest

Tabel 8.

Data Skor Akhir Kemampuan Berpikir Reflektif Matematis Siswa

\begin{tabular}{|c|c|c|c|c|c|}
\hline $\begin{array}{c}\text { Kelompok } \\
\text { Penelitian }\end{array}$ & $\begin{array}{c}\text { Banyak } \\
\text { Siswa }\end{array}$ & Rata-rata & $\begin{array}{c}\text { Simpangan } \\
\text { Baku }\end{array}$ & $\begin{array}{c}\text { Nilai } \\
\text { Terendah }\end{array}$ & $\begin{array}{c}\text { Nilai } \\
\text { Tertinggi }\end{array}$ \\
\hline Eksperimen & 30 & 76,4 & 4,19 & 70 & 87 \\
\hline Kontrol & 30 & 72,82 & 6,97 & 40,625 & 81 \\
\hline
\end{tabular}

Nilai Maksimum Ideal $(\mathrm{NMI})=100$

Tabel 9.

Data Skor Akhir Self-Efficacy Siswa

\begin{tabular}{|c|c|c|c|c|c|}
\hline $\begin{array}{c}\text { Kelompok } \\
\text { Penelitian }\end{array}$ & $\begin{array}{c}\text { Banyak } \\
\text { Siswa }\end{array}$ & Rata-rata & $\begin{array}{c}\text { Simpangan } \\
\text { Baku }\end{array}$ & $\begin{array}{c}\text { Skor } \\
\text { Terendah }\end{array}$ & $\begin{array}{c}\text { Skor } \\
\text { Tertinggi }\end{array}$ \\
\hline Eksperimen & 30 & 70,4 & 17,56 & 57,3 & 88,5 \\
\hline Kontrol & 30 & 55,17 & 7,54 & 43,75 & 68,75 \\
\hline
\end{tabular}

Skor Maksimum Ideal (SMI) $=96$

Berdasarkan Tabel 7 dan 8 memperlihatkan bahwa rata-rata kemampuan akhir berpikir reflektif matematis dan self-efficacy siswa kelas eksperimen lebih tinggi daripada rata-rata kemampuan akhir berpikir reflektif matematis dan self-efficacy siswa kelas kontrol. Selanjutnya, untuk menguji apakah ada perbedaan kemampuan akhir berpikir reflektif matematis dan self-efficacy kedua kelas sampel yang juga berlaku pada populasi maka dilakukan analisis data. 
Dari hasil uji normalitas dan uji homogenitas sebagai uji prasyarat sebelum melakukan uji t, diketahui bahwa data skor awal kemampuan berpikir reflektif matematis dan self-efficacy siswa pada kedua sampel dalam penelitian ini berasal dari populasi yang berdistribusi normal dan kedua kelompok populasi memiliki varian yang homogen atau sama. Oleh karena itu, uji hipotesis menggunakan uji kesamaan dua rata-rata, yaitu uji $t$. Dengan menggunakan program SPPS versi 20.0, diperoleh hasil sepertii pada Tabel 9 dan 10.

\section{Tabel 10.}

Hasil Uji t Skor Akhir Kemampuan Berpikir Reflektif Matematis

\begin{tabular}{|l|c|c|c|c|}
\hline Pembelajaran & Rata-Rata & Z & df & Sig. (2-tailed) \\
\cline { 1 - 2 } PBM hasil Pengembangan & 76,4 & & & \\
\cline { 1 - 3 } $\begin{array}{l}\text { PBM sebelum } \\
\text { pengembangan }\end{array}$ & 72,82 & $-2,333$ & 58 & 0,023 \\
\hline
\end{tabular}

Selanjutnya, dari hasil uji normalitas dan uji homogenitas sebagai uji prasyarat sebelum melakukan uji t, diketahui bahwa data skor self-efficacy siswa pada kedua sampel dalam penelitian ini berasal dari populasi yang berdistribusi normal dan kedua kelompok populasi memiliki varian yang homogen atau sama. Oleh karena itu, uji hipotesis menggunakan uji kesamaan dua rata-rata, yaitu uji $t$. Dengan menggunakan program SPPS versi 20.0, diperoleh hasil seperti pada Tabel 10.

\section{Tabel 11.}

Hasil Uji t Skor Akhir Self-Efficacy Siswa

\begin{tabular}{|c|c|c|c|c|}
\hline Pembelajaran & $\begin{array}{l}\text { Rata- } \\
\text { Rata }\end{array}$ & $\mathbf{t}_{\text {hitung }}$ & $D f$ & Sig. (2-tailed) \\
\hline PBM hasil Pengembangan & 70,4 & \multirow[t]{2}{*}{6,148} & \multirow[t]{2}{*}{58} & \multirow[t]{2}{*}{0,000} \\
\hline $\begin{array}{l}\text { PBM sebelum } \\
\text { pengembangan }\end{array}$ & 55,17 & & & \\
\hline
\end{tabular}

Berdasarkan Tabel 9 dan Tabel 10, terlihat bahwa nilai probabilitas (Sig.) kurang dari 0,05. Ini berarti bahwa hipotesis nol ditolak, sehingga dapat disimpulkan bahwa ada perbedaan yang signifikan antara kemampuan akhir berpikir reflektif matematis dan self-efficacy siswa yang menggunakan pembelajaran PBM yang dikembangkan dan siswa yang tidak menggunakan pembelajaran PBM yang dikembangkan.

Hasil tersebut ternyata belum dapat menjawab hipotesis dari penelitian ini. Oleh karena itu, dilakukan uji hipotesis lanjutan untuk mengetahui apakah kemampuan akhir berpikir reflektif matematis dan self-efficacy siswa yang menggunakan pembelajaran PBM yang dikembangkan lebih tinggi dari kemampuan akhir berpikir reflektif matematis dan self-efficacy siswa yang tidak menggunakan pembelajaran PBM yang dikembangkan.

Berdasarkan hasil kemampuan awal berpikir reflektif matematis dan self-efficacy siswa pada kedua kelas sama, maka analisis lanjutan dapat dilihat dari rata-rata skor posttest dan rata-rata skor 
Pengembangan PBM Dengan Tahapan TPS untuk Meningkatkan Kemampuan Berpikir Reflektif Matematis dan SelfEfficacy Siswa, Indri Cahya Kusuma, Sri Hastuti Noer, Caswita

akhir self-efficacy kedua kelas. Pada Tabel 9 terlihat bahwa rata-rata skor posttest kelas yang menggunakan pembelajaran PBM yang dikembangkan lebih tinggi daripada kelas yang tidak menggunakan pembelajaran PBM yang dikembangkan. Kemudian pada Tabel 10 terlihat bahwa ratarata skor akhir self-efficacy kelas yang menggunakan pembelajaran PBM yang dikembangkan lebih tinggi daripada kelas yang tidak menggunakan pembelajaran PBM yang dikembangkan. Dengan demikian dapat ditarik kesimpulan bahwa kemampuan berpikir reflektif matematis dan self-efficacy siswa yang menggunakan pembelajaran PBM yang dikembangkan lebih tinggi daripada kemampuan berpikir reflektif matematis dan self-efficacy siswa yang tidak menggunakan pembelajaran PBM yang dikembangkan, dengan kata lain model pembelajaran PBM yang dikembangkan engan tahapan TPS ini efektif untuk meningkatkan kemampuan berpikir reflektif dan self-efficacy siswa.

\section{Analisis Indeks Gain Kemampuan Berpikir Reflektif Matematis dan Self-Efficacy Siswa}

Pada analisis kemampuan awal berpikir reflektif matematis dan self-efficacy siswa didapat bahwa siswa pada kelas eksperimen maupun kelas kontrol mempunyai kemampuan awal berpikir reflektif matematis danself-efficacy yang sama. Selanjutnya dilakukan analisis indeks gain kemampuan berpikir reflektif matematisdan self-efficacysiswa untuk mengetahui bagaimana peningkatan kemampuan berpikir reflektif matematis dan self-efficacy siswa pada kedua kelas. Setelah dilakukan perhitungan indeks gain dari data pretest dan skor awal self-efficacy dengan dataposttest dan skor akhir self-efficacy diperoleh data yang disajikan pada Tabel 12 dan 13.

\section{Tabel 12.}

Data Indeks Gain Kemampuan Berpikir Reflektif Matematis Siswa

\begin{tabular}{|c|c|c|c|c|c|c|c|}
\hline No & Kelas & Nilai & $\mathbf{N}$ & $X_{\min }$ & $X_{\text {maks }}$ & $\bar{x}$ & $\begin{array}{l}\text { Rerata } \\
N \text {-gain }\end{array}$ \\
\hline \multirow[t]{2}{*}{1} & \multirow[t]{2}{*}{ Eksperimen } & Pretest & \multirow[t]{2}{*}{30} & 31 & 66 & 52,56 & \multirow[t]{2}{*}{0,502} \\
\hline & & Posttest & & 70 & 87 & 76,4 & \\
\hline \multirow[t]{2}{*}{2} & \multirow[t]{2}{*}{ Kontrol } & Pretest & \multirow[t]{2}{*}{30} & 31 & 78 & 57,87 & \multirow[t]{2}{*}{0,386} \\
\hline & & Posttest & & 65 & 81 & 73,9 & \\
\hline
\end{tabular}

Tabel 13.

Data Indeks Gain Self-Efficacy Siswa

\begin{tabular}{|c|c|c|c|c|c|c|c|}
\hline No & Kelas & Nilai & $\mathbf{N}$ & $X_{\min }$ & $X_{\text {maks }}$ & $\bar{x}$ & $\begin{array}{l}\text { Rerata } \\
N \text {-gain }\end{array}$ \\
\hline \multirow[t]{2}{*}{1} & \multirow[t]{2}{*}{ Eksperimen } & Pretest & \multirow[t]{2}{*}{34} & 43,8 & 71,9 & 54,9 & \multirow[t]{2}{*}{0,343} \\
\hline & & Posttest & & 70,4 & 88,5 & 70,4 & \\
\hline \multirow[t]{2}{*}{2} & \multirow[t]{2}{*}{ Kontrol } & Pretest & \multirow[t]{2}{*}{34} & 43,75 & 68,75 & 55,17 & \multirow[t]{2}{*}{0,07} \\
\hline & & Posttest & & 46,88 & 76,04 & 58,69 & \\
\hline
\end{tabular}

Pada Tabel 12 di atas memperlihatkan bahwa rata-rata indeks gain kemampuan berpikir reflektif matematis siswa yang menggunakan pembelajaran PBM yang dikembangkan lebih tinggi daripada rata-rataindeks gain kemampuan berpikir reflektif matematis siswa yang tidak menggunakan 
pembelajaran PBM yang dikembangkan. Berdasarkan Tabel 12 rata-rata indeks gain kelas eksperimen adalah 0,502 dan indeks gain kelas kontrol adalah 0,386. Hal ini berarti bahwa peningkatan kemampuan berpikir reflektif matematis siswa yang menggunakan pembelajaran PBM yang dikembangkan termasuk dalam peningkatan dengan kriteria sedang, sedangkan peningkatan kemampuan berpikir reflektif matematis siswa yang tidak menggunakan pembelajaran PBM yang dikembangkan termasuk dalam peningkatan dengan kriteria sedang.

Pada Tabel 13 di atas memperlihatkan bahwa rata-rata indeks gain self-efficacy siswa yang menggunakan pembelajaran PBM yang dikembangkan lebih tinggi daripada rata-rata indeks gain selfefficacy siswa yang tidak menggunakan pembelajaran PBM yang dikembangkan. Berdasarkan Tabel 4.32 rata-rata indeks gain kelas eksperimen adalah 0,343 dan indeks gain kelas kontrol 0,07. Hal ini berarti bahwa peningkatan self-efficacy siswa yang menggunakan pembelajaran PBM yang dikembangkan termasuk dalam peningkatan dengan kriteria sedang, sedangkan peningkatan selfefficacy siswa yang tidak menggunakan pembelajaran PBM yang dikembangkan termasuk dalam peningkatan dengan kriteria rendah.

\section{KESIMPULAN}

Berdasarkan hasil analisis data dan pembahasan, diperoleh kesimpulan bahwa hasil akhir dari penelitian pengembangan ini adalah pengembangan model PBM dengan tahapan TPS yang difasilitasi dengan LKPD. PBM dengan tahapan TPS memiliki kevalidan, kepraktisan, dan kemenarikan yang baik dan efektif dalam meningkatkan kemampuan berpikir reflektif matematis dan self-efficacy siswa.

\section{DAFTAR PUSTAKA}

Arky, dkk. (2017). Penerapan pembelajaran kooperatif tipe Think-Pair-Share (TPS) untuk meningkatkan hasil belajar siswa . Jurnal Chemica Vo/. 18 Nomor 2 Desember 2017,71-79. Makasar

Bandura, Albert. 2002. Self efficacy: The Exercise of Control. New York : W. H. Freeman \& Company

Borg dan Gall. (1989). Educational Research. New York: The Word Bank.

Dewey, J. 1933. How We Think : A Restatement of The Relation of Reflective Thinking to

The Educative Process. Boston, MA: D.C. Heath and Company

Depdiknas .2006. Permendiknas No 22 Tahun 2006 Tentang Standar Isi. Jakarta: Depdiknas

Herman,Tatang. 2007. Pembelajaran Berbasis Masalah untuk Meningkatkan Kemampuan

Berpikir Matematis Tingkat Tinggi Siswa Sekolah. [online]. Tersedia : http://file.upi.edu/Direktori/JURNAL/EDUCATIONIST/Vol. I No. 1-

Januari_2007/6._Tatang_Herman.pdf 
Pengembangan PBM Dengan Tahapan TPS untuk Meningkatkan Kemampuan Berpikir Reflektif Matematis dan SelfEfficacy Siswa, Indri Cahya Kusuma, Sri Hastuti Noer, Caswita

Hidayatun, Septi.(2015). Efektivitas Model Pembelajaran Kooperatiftipethink Pair Share (TPS) Ditinjau Dari Pemahaman Konsep Matematika Siswa Kelas Vii Di Smp N 3 Jetis.tidak dipublikasikan. Yogyakarta. Universitas PGRI Yogyakarta

Huda,M.2015. Model-model Pengajaran dan Pembelajaran. Yogyakarta: Pustaka pelajar,

Sanjaya, Wina. 2007. Strategi Pembelajaran Berorientasi Standar Proses. Pendidikan. Jakarta:

Kencana Prenada Media Group

Suharna, Hery. 2013. Berfikir Reflective (Reflektive Thinking) Mahasiswa Calon Guru

Dalam Pembelajaran. KNM XVI Unpad. Bandung

Suprihatiningrum, J. 2013.Strategi Pembelajaran (Teori dan Aplikasi).Yogyakarta: Ar-Ruzz Media, 